\title{
Challenging the six-minute myth of online video lectures: Can interactivity expand the attention span of learners?
}

\author{
Nitza Geri, The Open University of Israel, nitzage@openu.ac.il \\ Amir Winer, The Open University of Israel, amirwi@openu.ac.il \\ Beni Zaks, The Open University of Israel, beniza@openu.ac.il
}

\begin{abstract}
Keeping learners engaged in viewing online video lectures is a challenge, which is considered harder as the length of the video is longer. Although it is a known obstacle, in practice, many videos are lengthy and do not contain interactive elements. This study takes an attention economy perspective, and examines if interactivity may enable effective use of longer online video lectures. Google Analytics data was used to measure average online video lecture viewing completion percentage for two 'long' and 'short' video lecture groups, before and after the addition of interactive components. Preliminary results show that addition of interactivity significantly improved completion percentage as well as average viewing time for both 'long' and 'short' video lecture groups by more than 20\%. Furthermore, the average viewing time of the 'long' group grew to over 10 minutes. The contributions of this study are twofold: it demonstrates the potential of learning analytics to identify ways to improve learning processes, and it provides empirical support for the potential of adding interactive elements to the videos to expand the attention span of learners.
\end{abstract}

Keywords: Online video lectures, interactive video, learner attention span, human computer interaction (HCI), distance learning, learning analytics, attention economy

\section{Introduction}

Attention is considered as the scarcest resource in our information overloaded world (Davenport \& Beck, 2001). E-learning has improved the possibilities of learners beyond traditional distance learning (Levy \& Ramim, 2015) by offering them diverse learning activities, which are available anytime, anywhere. Hence, e-learning enables learners to study whenever they have the necessary time and attention resources (Geri, 2012).

Online video lectures are an important learning technology within e-learning because they provide learners with rich experience, similar to face-to-face learning (Nord, Paliszkiewicz, \& Koohang, 2014; Siemens, Gašević, \& Dawson, 2015). However, student retention, which is a major challenge of distance learning, remains a problem in courses that are based on online video lectures (Geri, Gafni, \& Winer, 2014; Guri-Rosenblit, 2009; Kim, Guo, Seaton, Mitros, Gajos, \& Miller, 2014). Paradoxically, it seems that the availability of online video lectures increases student dropout, even by students that are enrolled in face-to-face classes. Since the students 
have access to these online lectures, they skip classes, and procrastinate their learning until it is too late (Geri \& Winer, 2015).

One of the disadvantages of online video lectures is that it is hard for learners to passively watch them. Adding interactivity increases the effectiveness of the lectures and expands the attention span of online learners (Cherrett, Wills, Price, Maynard, \& Dror, 2009; Dror, Schmidt, \& O'connor, 2011; Kim et al., 2014). Interactivity has been considered for years an essential element of learning (Moreno \& Mayer, 2007; Sims, 1997). However, adding an interactive layer requires a significant investment in pedagogical as well as technological resources. Kilb, RazLiebermann, and Katz (2001) developed a model for interactive coaching, and used it for designing a comprehensive coaching environment for volleyball that included a database with 400 full video drills, 250 educational practice notes, a glossary of volleyball related terms, as well as modules that enabled the coaches to modify the drills. Although it may seem that such massive investment may not be necessary for developing many other learning environments, there are several general design principles that Kilb et al. (2001) used, which are relevant for effective planning of most interactive learning environments, such as analyzing the needs of both instructors and learners, identifying different types of learners and providing them with appropriate interactive content, and letting the users modify the system according to their needs.

Midoro et al. (1988) characterized interactivity by three properties: adaptivity, reactivity, and flexibility, and suggested Artificial Intelligence (AI) techniques for assisting learners in interactive video learning environments. It is essential to evaluate the effectiveness of interactive media (Laurillard \& Taylor, 1994), and previous studies such as Hannafin and Colamaio (1987), demonstrated the value of interactive video as a specific media for learning. However, prior research examined mainly controlled situations in which different learning environments were compared, and learners experienced different situations (Zhang, Zhou, Briggs, \& Nunamaker, 2006). This study examines the effect of interactivity on attention and video retention rather than the effect of interactivity on learning. Furthermore, current online learning environments challenge e-learners with many obstructions that may divert their attention. These concerns suggest a higher possibility of additional distraction that may be caused by in-video interactivity.

Policy makers have long been considering interactive online learning as a means to reduce costs (Bowen, Chingos, Lack, \& Nygren, 2014). Recently, Massive Open Online Courses (MOOCs) have evolved as an affordable way to provide open access to learning and support higher rates of inclusion. However, student retention is one of the major challenges of MOOCs (Daniel, 2012; de Freitas, Morgan, \& Gibson, 2015). There are multiple causes for student dropout from MOOCs, but in the context of this study, it should be noted that online video lectures are a main component of many MOOCs. Moreover, concerning the attention span of MOOC learners, according to the six minutes' 'myth', engagement time, regardless of the length of the video lecture, is at most six minutes (Lagerstrom, Johanes, \& Ponsukcharoen, 2015). Therefore, the practical advice is to cut video lectures to small chunks.

Nevertheless, in learning contexts, sometimes the message is complex, or cannot be transferred in a short format. Furthermore, although it seems simple to keep online lectures short, it appears that instructors are reluctant to do so. It takes time, efforts, and resources to prepare short video lectures. As the famous quote, attributed to Blaise Pascal, Mark Twain, and several others, claims: "If I had more time, I would have written a shorter letter". 


\section{Research Objectives}

This study takes an attention economy perspective (Davenport \& Beck, 2001; Geri \& Geri, 2011) and applies learning analytics (Dawson \& Siemens, 2014; Persico \& Pozzi, 2015) to identify effective policies for utilization of learning technologies. Specifically, the purpose of this study is to examine whether the addition of interactive elements may enable effective use of longer online video lectures. In economics terminology, we investigate if interactivity and video length are substitutes in the sense that adding interactivity and shortening online video lectures are two options that either could be used to increase the effectiveness of the lectures.

Rather than technically deploying resources for shortening online video lectures, the insertion of interactive components such as multiple-choice questions, quizzes, or other interactive elements, may improve learning as well as increase the attention span of learners. Thus, adopting such a policy by academic institutions may be beneficial to all stakeholders: students, instructors, pedagogical and technical staffs who support learning technologies adoption and continued use, institutions' managements, and society at large.

\section{Methodology}

This study took place at the Open University of Israel (OUI), and analyzed data of MOOCs that were developed with the aim of making English language proficiency preparation freely accessible to Israeli students in higher education institutions. All undergraduate Israeli students, whether studying at a university or a college, must take a series of exams in English for academic purposes (EAP) until they reach an exemption level. The initial EAP level is determined by a national exam. Usually, the academic institution offers a series of courses to prepare the students for the following internal exams and charges additional tuition fees for each course.

In 2015, the Israeli Council for Higher Education called upon the OUI to develop four MOOCs, two pre-basic EAP courses, a basic level course, and an advanced one. The highest level EAP course was not included in the project, and the students were required to study that course within their academic institution. On the first stage of the project (from January 1, 2016 until August 6, 2016) the developed EAP MOOCs included online video lectures and basic exercises. During the second stage of the project, which started on August 7, 2016, the online video lectures provided interactive assessment and feedback through the use of advanced technological tools.

In order to examine the effect of interactivity on the attention span of learners, as measured by their viewing completion percentage of 'short' and 'long' lectures, we analyzed aggregate viewing data of the online video lectures that were the main instructional method of these MOOCs. At the first stage of the MOOCs (i.e., until August 6, 2016) no registration was required and no data was available at the individual student level.

We selected analyzing the two higher levels of the MOOCs: the basic and advanced courses, because we wanted to decrease a possible influence of dropout that was caused by inability to cope with the academic requirements. The entire online video lectures of both courses were examined. Few outlier videos were excluded because their aggregate viewing patterns suggested that they included a relatively extraordinary proportion of viewers who belonged to the 'sampling cluster' (Ferguson \& Clow, 2015), these were mainly the first videos of each study 
unit within the two MOOCs. Hence, the sample included 59 video lectures. More details about the sample are provided in the following section, as well as the division of the sample to two groups of 'long' and 'short' videos.

The online video lecture viewing data was obtained from Google Analytics (GA) (Clifton, 2012). Complete actual viewing data was used (i.e., not sample data that GA automatically provides for large datasets, which may be circumvented by using multiple queries for shorter periods, and combining the queries' results).

\section{Results}

Table 1 presents a descriptive comparison of the entire sample of 59 online video lectures before and after the addition of interactive questions to the videos (hereafter, the intervention). Both average and median results are reported due to several reasons: the videos were relatively new and there might have been uncharacteristic viewing patterns, e.g., by instructors who would like to explore the videos and their potential as complementing face-to-face learning; the period after the intervention was relatively short and occurred before the beginning of the academic year so some of the viewing patterns may not represent actual learning activities. However, as observed in Table 1, as well as in subsequent results presented in this section, the average and median results are quite similar.

The data in Table 1 shows that the addition of interactive elements to the videos increased their viewing metrics. The statistical analysis indicated that the changes are significant. However, these results are not presented in this paper because this study is focused on the length of online video lectures and the potential of interactivity to increase the effectiveness of relatively long videos, as measured by their viewing completion percentage.

The same 59 videos were used before and after the intervention, and their length ranged between 4.06 minutes to 24.03 minutes, with a mean of 11.78 minutes and 4.46 minutes' standard deviation (SD). The median value was 10.49 minutes. Therefore, the cutoff point for examining the effect of the intervention on completion percentage of viewing 'short' and 'long' video lectures was set to 11 minutes. There were 30 videos shorter than 11 minutes, and 29 videos longer than (including equal to) 11 minutes. Table 2 shows the online video lecture viewing mean and median completion percentage, as well as their respective SD, before and after the intervention, for the two groups.

Figure 1 illustrates average video lecture viewing completion percentage for the 'long' and 'short' groups, before and after the intervention. As Figure 1 demonstrates, the intervention significantly increased the average completion percentage for both groups: by $22.61 \%$ for the 'long' group (from 59.13\% to $72.50 \%$ ), and by $25.02 \%$ for the 'short' group (from $63.46 \%$ to $79.34 \%$ ). The paired samples two-tailed t-test results for the 'short' group are $\mathrm{t}=-19.75,29$ degrees of freedom (df), $\mathrm{p}<.0001$, and for the 'long' group $\mathrm{t}=-9.67,28 \mathrm{df}, \mathrm{p}<.0001$. 
Table 1. Descriptive comparison of video lecture viewing

\begin{tabular}{|l|l|l|}
\hline & $\begin{array}{l}\text { Before } \\
\text { (no interaction) }\end{array}$ & $\begin{array}{l}\text { After } \\
\text { (interaction) }\end{array}$ \\
\hline Period & Jan. 1, 2016 - Aug. 6, 2016 & Aug. 7, 2016 - Sep. 26, 2016 \\
\hline Days & 218 & 51 \\
\hline Total views & 85,303 & 23,032 \\
\hline Total time viewed & 497,262 minutes & 180,288 minutes \\
\hline $\begin{array}{l}\text { Average views per calendar } \\
\text { day }\end{array}$ & 391 & 452 \\
\hline $\begin{array}{l}\text { Average video view duration } \\
\text { (standard deviation) }\end{array}$ & $\begin{array}{l}7.17 \text { minutes } \\
(2.35)\end{array}$ & $\begin{array}{l}8.79 \text { minutes } \\
(2.65)\end{array}$ \\
\hline $\begin{array}{l}\text { Median video view duration } \\
\text { (standard deviation) }\end{array}$ & $\begin{array}{l}6.93 \text { minutes } \\
(2.16)\end{array}$ & $\begin{array}{l}8.98 \text { minutes } \\
(2.67)\end{array}$ \\
\hline $\begin{array}{l}\text { Average completion } \\
\text { percentage; n=59 } \\
\text { (standard deviation) }\end{array}$ & $\begin{array}{l}61.33 \% \\
(6.61)\end{array}$ & $\begin{array}{l}75.98 \% \\
(7.56)\end{array}$ \\
\hline $\begin{array}{l}\text { Median completion } \\
\text { percentage; n=59 } \\
\text { (standard deviation) }\end{array}$ & $\begin{array}{l}59.73 \% \\
(6.99)\end{array}$ & $\begin{array}{l}77.66 \% \\
(8.31)\end{array}$ \\
\hline
\end{tabular}

Table 2. Online video lecture viewing completion percentage

\begin{tabular}{|l|l|l|l|l|}
\hline Setting & $\begin{array}{l}\text { Videos length } \\
\text { (minutes) }\end{array}$ & $\mathbf{n}$ & Mean (\%) & $\begin{array}{l}\text { Standard } \\
\text { deviation }\end{array}$ \\
\hline \multirow{2}{*}{$\begin{array}{l}\text { Before (no interaction) } \\
\text { Average }\end{array}$} & $>=11$ & 29 & 59.13 & 6.77 \\
\cline { 2 - 5 } & $<11$ & 30 & 63.46 & 5.79 \\
\hline \multirow{2}{*}{$\begin{array}{l}\text { Before (no interaction) } \\
\text { Median }\end{array}$} & $>=11$ & 29 & 56.48 & 6.50 \\
\cline { 2 - 5 } & $<11$ & 30 & 62.88 & 6.02 \\
\hline \multirow{2}{*}{$\begin{array}{l}\text { After (interaction) } \\
\text { Average }\end{array}$} & $>=11$ & 29 & 72.50 & 8.06 \\
\cline { 2 - 5 } & $<11$ & 30 & 79.34 & 5.26 \\
\hline \multirow{2}{*}{$\begin{array}{l}\text { After (interaction) } \\
\text { Median }\end{array}$} & $>=11$ & 29 & 74.04 & 8.39 \\
\cline { 2 - 5 } & $<11$ & 30 & 81.17 & 6.64 \\
\hline
\end{tabular}




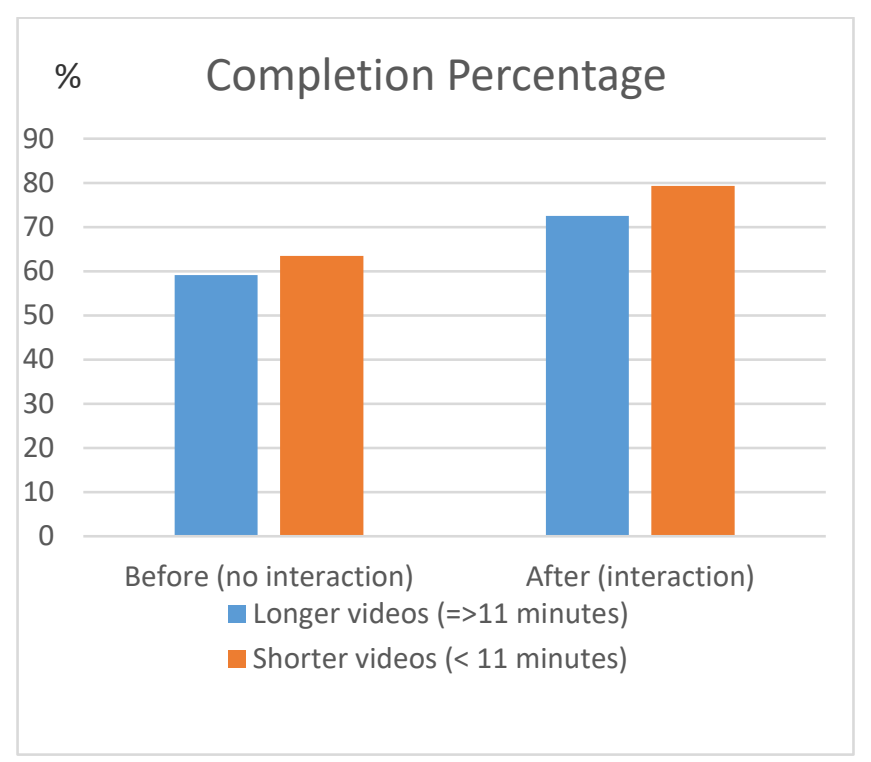

Figure 1. Video lecture viewing completion percentage

As shown in Figure 1 and Table 2, before the intervention, the differences between the average completion percentage of video lectures viewing of the 'long' group (mean $=59.13 \%, \mathrm{SD}=6.77$ ) and the 'short' group (mean $=63.46 \%, \mathrm{SD}=5.79$ ) were rather small. Hence, for practical purposes the completion rates of the two groups could be considered as similar. However, these differences were statistically significant, with a medium effect size $(\mathrm{t}=-2.647, \mathrm{p}=.01,57 \mathrm{df}$, equal variances assumed, Levene's test for equality of variances: $F=.216, p=.643$, Cohen's $d=.687$ ).

After the addition of interactive questions to the online video lectures, the differences between the average completion percentage of the two groups increased: $72.50 \%(\mathrm{SD}=8.06)$ for the 'long' group, and 79.34\% ( $\mathrm{SD}=5.26)$ for the 'short' group. The differences were statistically significant with a large effect size ( $\mathrm{t}=-3.875, \mathrm{p}<.001,57 \mathrm{df}$, equal variances assumed, Levene's test for equality of variances: $\mathrm{F}=3.476, \mathrm{p}=.067$, Cohen's $\mathrm{d}=1.005$ ).

Table 3 presents the online video lecture mean and median viewing time and their SD, before and after the intervention, for the 'long' and 'short' groups. The rest of the section presents the analysis of the mean data, as they were similar to the median data. Figure 2 shows average video lecture viewing time in minutes for the 'long' and 'short' groups, before and after the intervention.

The data in Table 3 and Figure 2 demonstrate that the intervention increased the average viewing time by $21.87 \%$ for the 'long' group (from 8.87 to 10.81 minutes), and by $24.55 \%$ for the 'short' group (from 5.50 to 6.85). The paired samples two-tailed t-test results for the 'short' group are $\mathrm{t}=-18.22,29$ degrees of freedom $(\mathrm{df}), \mathrm{p}<.0001$, and for the 'long' group $\mathrm{t}=-11.96,28 \mathrm{df}, \mathrm{p}<.0001$.

Table 3 and Figure 2 reveal evident differences between the average viewing times of online video lectures of the two groups before (3.37 minutes), as well as after (3.96 minutes), the intervention. Before the intervention, the average viewing time of the 'long' group (mean=8.87 minutes, $\mathrm{SD}=1.95$ ) and the average viewing time of the 'short' group (mean=5.50 minutes, $\mathrm{SD}=1.25)$ were statistically significant, with a large effect size $(\mathrm{t}=-7.88, \mathrm{p}<.0001,47.28 \mathrm{df}$, equal 
variances not assumed, Levene's test for equality of variances: $F=2.46, p=.009$, Cohen's $\mathrm{d}=2.058$ ).

Table 3. Online video lecture viewing time

\begin{tabular}{|l|l|l|l|l|}
\hline Setting & $\begin{array}{l}\text { Videos length } \\
\text { (minutes) }\end{array}$ & $\mathbf{n}$ & $\begin{array}{l}\text { Mean } \\
\text { (minutes) }\end{array}$ & $\begin{array}{l}\text { Standard } \\
\text { deviation }\end{array}$ \\
\hline \multirow{2}{*}{$\begin{array}{l}\text { Before (no interaction) } \\
\text { Average }\end{array}$} & $>=11$ & 29 & 8.87 & 1.95 \\
\cline { 2 - 5 } & $<11$ & 30 & 5.50 & 1.25 \\
\hline $\begin{array}{l}\text { Before (no interaction) } \\
\text { Median }\end{array}$ & $>=11$ & 29 & 8.50 & 1.80 \\
\cline { 2 - 5 } & $<11$ & 30 & 5.70 & 1.26 \\
\hline \multirow{2}{*}{$\begin{array}{l}\text { After (interaction) } \\
\text { Average }\end{array}$} & $>=11$ & 29 & 10.81 & 2.08 \\
\cline { 2 - 5 } & $<11$ & 30 & 6.85 & 1.37 \\
\hline \multirow{2}{*}{$\begin{array}{l}\text { After (interaction) } \\
\text { Median }\end{array}$} & $>=11$ & 29 & 10.25 & 2.02 \\
\cline { 2 - 5 } & $<11$ & 30 & 7.30 & 1.44 \\
\hline
\end{tabular}

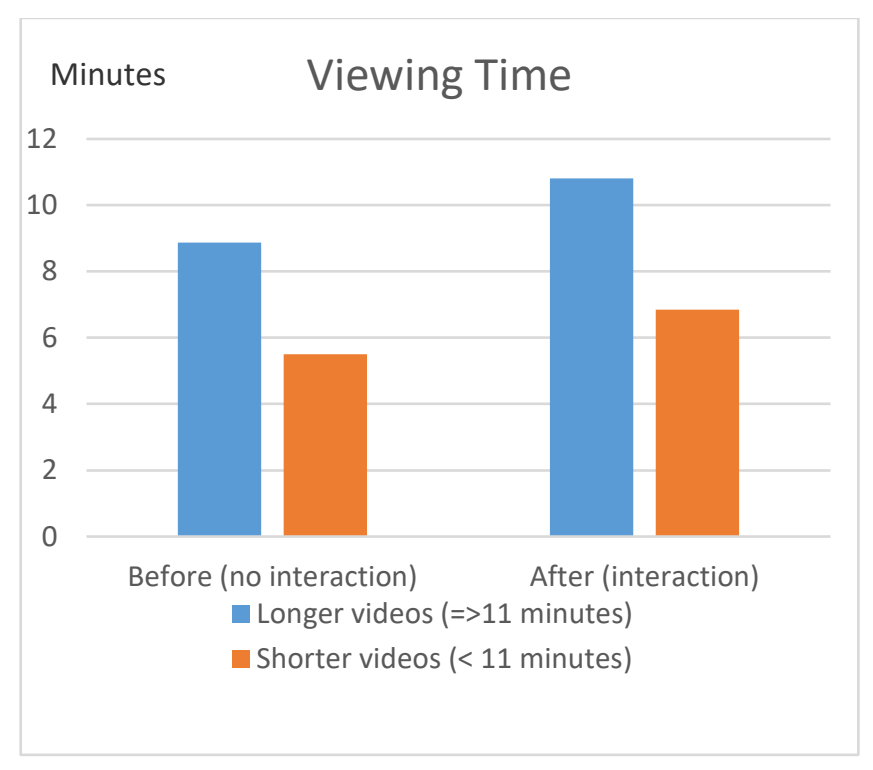

Figure 2. Video lecture viewing time

After the intervention, the differences between the average viewing time of the two groups increased by $17.51 \%$ to 3.96 minutes: 10.81 minutes $(\mathrm{SD}=2.08)$ for the 'long' group, and 6.85 minutes $(\mathrm{SD}=1.37)$ for the 'short' group. As before, the differences were statistically significant with a large effect size $(\mathrm{t}=-8.61, \mathrm{p}<.0001,48.11 \mathrm{df}$, equal variances not assumed, Levene's test for equality of variances: $\mathrm{F}=2.32, \mathrm{p}=.014$, Cohen's $\mathrm{d}=2.249$ ). 


\section{Discussion, Conclusions, and Further Research}

Our preliminary results indicate that the addition of interactivity significantly improved completion percentage as well as average viewing time for both long' and 'short' video lecture groups by more than $20 \%$. The analysis included the first 51 calendar days after the interaction, and as mentioned above, this period was during the summer break, before the beginning of the academic year. Yet, in addition to the promising completion percentage results, the data presented in Table 1 shows an increase in the average views per calendar day from 391 to 452 views after the intervention.

It may be argued that the attention span of learners is bounded (Simon, 1957, 1971), and therefore, if the online video lecture is shorter, there is a greater chance that the whole lecture will be viewed. However, our findings suggest otherwise, and join those who refute the 'six minutes' myth' (Lagerstrom et al., 2015). Specifically, the average viewing time of the 'long' group grew to 10.81 minutes, and even the average viewing time of the 'short' group increased to 6.85 minutes. Nevertheless, further research is needed to improve the understanding of how interactive elements may increase the effectiveness of online video lectures. Examining the potential of gamification to improve student engagement in e-learning environments (Osipov, Nikulchev, Volinsky, \& Prasikova, 2015) is another research direction that should be further pursued.

This study contributes to both theory and practice by demonstrating the potential of learning analytics to identify ways to improve learning processes, and by providing empirical support for the potential of adding interactive elements to online video lectures to expand the attention span of learners.

\section{Acknowledgement}

We would like to dedicate this paper to the memory of our colleague and friend, the late Dr. Tsily Raz-Liebermann. In her life, work and research, Tsily combined her passions for sports and educational technologies. May her generous spirit, wisdom and love forever inspire the instructional design, research and development at the Open University of Israel and beyond.

\section{References}

Bowen, W. G., Chingos, M. M., Lack, K. A., \& Nygren, T. I. (2014). Interactive Learning Online at Public Universities: Evidence from a Six Sigma Campus Randomized Trial. Journal of Policy Analysis and Management, 33(1), 94-111. http://dx.doi.org/ 10.1002/pam.21728

Cherrett, T., Wills, G., Price, J., Maynard, S., \& Dror, I. E. (2009). Making training more cognitively effective: Making videos interactive. British Journal of Educational Technology, 40(6), 1124-1134. http://dx.doi.org/10.1111/j.1467-8535.2009.00985.x

Clifton, B. (2012). Advanced web metrics with Google Analytics. Indianapolis: Wiley Publishing Inc. 
Daniel, J. (2012). Making sense of MOOCs: Musings in a maze of myth, paradox and possibility. Journal of Interactive Media in Education, 3 (Art. 18). http://doi.org/10.5334/2012-18

Dawson, S., \& Siemens, G. (2014). Analytics to literacies: The development of a learning analytics framework for multiliteracies assessment. The International Review of Research in Open and Distributed Learning, 15(4). Retrieved from http://www.irrodl.org/index.php/irrodl/article/view/1878/3006

Davenport, T. H., \& Beck, J. C. (2001). The attention economy: Understanding the new currency of business. Boston, MA: Harvard Business School Press.

de Freitas, S. I., Morgan, J., \& Gibson, D. (2015). Will MOOCs transform learning and teaching in higher education? Engagement and course retention in online learning provision.

British Journal of Educational Technology, 46(3), 455-471. http://doi.org/10.1111/bjet.12281

Dror, I., Schmidt, P. \& O'connor, L. (2011). A cognitive perspective on technology enhanced learning in medical training: Great opportunities, pitfalls and challenges. Medical Teacher, 33(4), 291-296. http://dx.doi.org/10.3109/0142159X.2011.550970

Ferguson, R., \& Clow, D. ( 2015). Examining engagement: Analysing learner subpopulations in massive open online courses (MOOCs). Proceedings of the Fifth International Conference on Learning Analytics and Knowledge (LAK'15), March 16 - 20, 2015, Poughkeepsie, NY, pp. 51-58. ACM. http://dx.doi.org/10.1145/2723576.2723606

Geri, N. (2012). The resonance factor: Probing the impact of video on student retention in distance learning. Interdisciplinary Journal of E-Learning and Learning Objects, 8, 1-13. Retrieved from http://www.ijello.org/Volume8/IJELLOv8p001-013Geri0794.pdf

Geri, N., Gafni, R., \& Winer, A. (2014). The u-curve of e-learning: Course website and online video use in blended and distance learning. Interdisciplinary Journal of E-Learning and Learning Objects, 10, 1-16. Retrieved from http://www.ijello.org/Volume10/IJELLOv10p001-016Geri0473.pdf

Geri, N., \& Geri, Y. (2011). The information age measurement paradox: Collecting too much data. Informing Science, 14, 47-59. Retrieved from http://www.inform.nu/Articles/Vol14/ISJv14p047-059Geri587.pdf

Geri, N., \& Winer, A. (2015). Patterns of online video lectures use and impact on student achievement. In Y. Eshet-Alkalai, I. Blau,A. Caspi, N. Geri, Y. Kalman, V. \& SilberVarod (eds.), Proceedings of the 10th Chais Conference for Innovation and Learning Technologies: Learning in the technological era, (pp. E9-E15), February 10-11, 2015, Raanana, The Open University of Israel. Retrieved from http://www.openu.ac.i1/innovation/chais2015/a1_2.pdf

Guri-Rosenblit, S. (2009). Digital technologies in higher education: Sweeping expectations and actual effects. New York, NY: Nova Science Publishers.

Hannafin, M. J., \& Colamaio, M. A. E. (1987). The effects of variations in lesson control and practice on learning from interactive video. Educational Technology Research and Development, 35(4), 203-212. http://dx.doi.org/ 10.1007/BF02766965 
Kilb, B., Raz-Liebermann, T., \& Katz, L. (2001). The role of technology in coaching: Enhancing the practice through education, drills databases and practice planning. Proceedings of the 3rd International Symposium of Computer Science in Sport (pp. 71-76), Centre for Performance Analysis, Cardiff, Wales. Retrieved from http://www.kin.ucalgary.ca/strc/volleyball/images/poster/PASSVballPaper8May01.pdf

Kim, J., Guo, P. J., Seaton, D. T., Mitros, P., Gajos, K. Z., \& Miller, R. C. (2014). Understanding in-video dropouts and interaction peaks in online lecture videos. Proceedings of the first ACM conference on Learning@ scale conference, March 04 - 05, 2014, Atlanta, GA, pp 31-40. ACM. http://dx.doi.org/10.1145/2556325.2566237

Lagerstrom, L., Johanes, P., \& Ponsukcharoen, M. U. (2015). The myth of the six-minute rule: Student engagement with online videos. Proceedings of the American Society for Engineering Education, June 14-17, 2015, Seattle, WA. Retrieved from https://www.asee.org/public/conferences/56/papers/13527/download

Laurillard, D., \& Taylor, J. (1994). Designing the stepping stones: An evaluation of interactive media in the classroom. Journal of Educational Television, 20(3), 169-84.

Levy, Y., \& Ramim, M. M. (2015). An assessment of competency-based simulations on elearners' management skills enhancements. Interdisciplinary Journal of e-Skills and Life Long Learning, 11, 179-190. Retrieved from http://www.ijello.org/Volume11/IJELLv11p179-190Levy1958.pdf

Midoro, V., Chioccariello, A., Olimpo, G., Persico, D., Sarti, L., \& Tavella, M. (1988). Interactive video and artificial intelligence: a convenient marriage. Innovations in Education and Training International, 25(4), 299-309. http://dx.doi.org/10.1080/1355800880250405

Moreno, R., \& Mayer, R. (2007). Interactive multimodal learning environments. Educational Psychology Review, 19(3), 309-326. http://dx.doi.org/ 10.1007/s10648-007-9047-2

Nord, J. H., Paliszkiewicz, J., \& Koohang, A. (2014). Using social technologies for competitive advantage: impact on organizations and higher education. Journal of Computer Information Systems, 55(1), 92-104.

Osipov, I. V., Nikulchev, E., Volinsky, A. A., \& Prasikova, A. Y. (2015). Study of gamification effectiveness in online e-learning systems. International Journal of advanced computer science and applications, 6(2), 71-77. Retrieved from https://pdfs.semanticscholar.org/b858/8ec4c150900d6d5c2ba165418d8a137046cb.pdf

Persico, D., \& Pozzi, F. (2015). Informing learning design with learning analytics to improve teacher inquiry. British Journal of Educational Technology, 46(2), 230-248. http://dx.doi.org/ 10.1111/bjet.12207

Siemens, G., Gašević, D. \& Dawson, S. (2015). Preparing for the digital university: A review of the history and current state of distance, blended, and online learning. Retrieved from http://linkresearchlab.org/preparingdigitaluniversity.pdf

Simon, H. A. (1957). Models of man: Social and rational. New York: John Wiley and Sons, Inc. 
Simon, H. A. (1971). Designing organizations for an information-rich world. In M. Greenberger (Ed.), Computers, communications and the public interest (pp. 40-41). Baltimore, MD: Johns Hopkins Press.

Sims, R. (1997). Interactivity: A forgotten art? Computers in Human Behavior, 13(2), 157-180. http://dx.doi.org/ 10.1016/S0747-5632(97)00004-6

Zhang, D., Zhou, L., Briggs, R. O., \& Nunamaker, J. F. (2006). Instructional video in e-learning: Assessing the impact of interactive video on learning effectiveness. Information \& management, 43(1), 15-27. http://dx.doi.org/10.1016/j.im.2005.01.004

\section{Authors' Biographies}

Nitza Geri is an Associate Professor at the Open University of Israel, Department of Management and Economics, and Head of the Research Center for Innovation in Learning Technologies. She holds a B.A. in Accounting and Economics and a Ph.D. in Technology and Information Systems Management from Tel-Aviv University. Nitza is a CPA (Israel) with over 12 years of business experience. Her research interests focus on the value of information and knowledge: strategic information systems, information economics, attention economy, knowledge management, value creation, Theory of Constraints, and effectiveness of e-learning. Personal site: http://www.openu.ac.il/en/personalsites/NitzaGeri.aspx

Amir Winer Heads the Interactive Courseware unit and the video production studio at the Open University of Israel. He served as a special digitation consultant for Israel's Ministry of Education and led the design of Israel's standard for developing K12 Digital Textbooks. Prior to joining the Open University of Israel, Amir was Head of R\&D at the Center for Futurism in Education at Ben Gurion University. Amir is a PhD candidate at Bar Ilan University and holds an MA in Psychology and a BA in Cognitive Science, both from Ben-Gurion University.

Beni Zaks leads the design and development initiatives at the Interactive Courseware unit at the Open University of Israel. He is responsible for maximizing student's learning experience by designing innovative learning courseware, integrating educational technologies and assimilating "Learning Analytics" practices and platforms. Prior to joining the Open University of Israel, Beni led a design studio and was involved in several innovative projects meshing design with new technologies. Beni holds an MA in Digital Art from the Universitat Pompeu Fabra in Barcelona and a B.Sc. in Technological Education and Industrial Design from the Holon Institute of Technology. 